Junaidi / 2017

\title{
KORUPSI, PERTUMBUHAN EKONOMI DAN KEMISKINAN DI INDONESIA
}

\author{
Junaidi, I Ketut Patra ${ }^{1}$ \\ * Sekolah Tinggi Ilmu Ekonomi Muhammadiyah Palopo \\ *Junaidi@stiem.ac.id
}

\begin{abstract}
Some countries have been faced to corruption stage. Especially developing region, corruption has became a disaster humankind and occur a global issue, because it is very disturbing cycle of the world economy. In many cases corruption related to financial report manipulation. One of the factor fraud rate is accounting have leave religion aspect in their report. A revolution of solution must be born in the globe. to reduces and combating the level of corruption, but on the other hand accounting makes corruption becomes more fertile. This research uses the literature approach and is expected to be one of the concepts for future research in conducting research on the prevention of corruption for accounting sector. Based on literature study we found that the approach to culture and religiosity in Indonesia will be more effective in preventing corruption. This is caused by the people of Indonesia, which consists of many tribes, cultures, beliefs and religions.
\end{abstract}

Keywords: corruption, accounting, religiosity

\section{Pendahuluan}

Dalam buku One Man's View of The World yang dirilis dua tahun sebelum berpulang, Lee Kuan Yew mengatakan, Indonesia merupakan negara yang dikaruniai sumber daya alam melimpah. Kekayaan alam itu semestinya bisa dijadikan salah satu modal untuk berkembang menjadi negara maju. Namun, Indonesia tak kunjung menjadi negara maju. Menurut pendiri Singapura itu, salah satu faktor penghambat kemajuan Indonesia adalah korupsi. Akibat korupsi, satu per satu kekayaan alam Indonesia habis tanpa menciptakan kemakmuran pada generasi-generasi berikutnya. Sampai sekarang kemakmuran itu sendiri seakan tidak pernah datang melainkan yang dirasakan adalah dampak negatif dari eksplorasi dari sumber daya alam tersebut berupa bencana alam dan konflik antar masyarakat yang disebabkan oleh potensi sumber daya alam tersebut (Kompas, 4 Juni 2015).

Saat ini Indonesia mengalami titik nadir terkait dengan masalah pertumbuhan ekonomi dan tingkat korupsi yang terus berkembang dan seakan-akan tidak pernah berhenti. Hampir setiap hari kita melihat dan mendenganr tentang fluktuasi nilai harga kebutuhan masyarakat, melemahnya nilai tukar rupiah, rendahnya pertumbuhan ekonomi, tingginya pengangguran dan meningkatnya keluarga miskin, disisi lain kita juga selalu disuguhi kasus korupsi yang melibatkan para

Riset Akuntansi dan Keuangan Indonesia, 3(1), 2018 politisi dan pejabat negara (eksekutif, legislatif dan yudikatif).

Setelah Indonesia menjadi negara demokrasi lebih dari satu dekade, banyak yang tergoda untuk bertanya apakah kasus korupsi yang merajalela selama periode ini sebenarnya adalah buah dari demokrasi. Menurut Olson (1993,2000) mengapa kesejahteraan tidak mengikuti jatuhnya sebuah pemerintahan yang buruk. Alasannya adalah perubahan politik dari komunis/otoriter ke demokrasi hanya merubah tipe korupsinya dan tipe penjahatnya yakni perubahan dari "penjahat yang diam (pasif)" menjadi "penjahat yang aktif'.

Penjahat yang diam tahu mereka akan berkuasa untuk jangka waktu yang lama. Mereka menjual perlindungan kepada para penjahat yang lebih kecil berkat monopoli kekuasaan mereka. Namun, ketika rezim berubah menjadi demokrasi, tipe penjahat ini berubah menjadi aktif dan lebih berbahaya dibandingkan dengan yang diam. Penjahat yang aktif menyadari bahwa mereka mempunyai waktu yang sedikit untuk berkuasa karena sistem demokrasi yang akhirnya melakukan praktek korupsi secara besar ketika mereka berkuasa.

Menurut Olson $(1993,2000)$ di Eropa Timur, demokrasi menciptakan korupsi yang lebih berbahaya lagi dibandingkan rezim militer, bahkan demokrasi itu mengarah kepada kerusuhan etnis, sektarian dan 
mengancam perpecahan di negara demokrasi baru, Agatiello (2010). Pendapat ini tentunya tidak sesuai dengan Alesina dan Drazen (1991); Shleifer dan Vishny (1993); Sandholtz dan Koetzle, (2000); Treisman, (2000); Tavares (2004); Mierau et al. (2007); Henderson dan Kuncoro (2011) yang menyatakan sistem demokrasi secara efektif mengurangi tindak korupsi. Menurut Jetter, Agudelo dan Hasan (2015) sistem demokrasi efektif mengurangi tindakan korupsi hanya terjadi pada dengan GDP lebih dari U\$ 2.000 namun dinegaranegara miskin demokrasi berubah menjadi bencana seperti kerusuhan etnis.

Menurut Hadiz dan Robinson (2004) di Indonesia demokrasi yang sebenarnya tidak pernah terjadi lagi setelah era Soeharto. Kekuatan oligarki bisnis dan politik mengambil kontrol lebih besar atas politik Indonesia dibandingkan dengan yang dilakukan para politisi dan masyarakat sipil itu sendiri, meskipun sebagian besar para pemimpin Barat memuji Indonesia sebagai negara muslim yang menerapkan sistem demokrasi.

Mahfud MD dalam wawancara dengan Metro TV (10/7/2015) menyatakan seluruh incumbent melakukan kecurangan dalam pemilihan kepala daerah dengan cara memobilisasi para PNS dan memanfaatkan fasilitas negara demi kepentingannya saja. Jika pemilukada dimenangi dengan cara yang tidak terpuji tidaklah pantas proses itu disebut proses demokrasi dan demokrasi itu sebenarnya tidak pernah ada karena suburnya praktek kecurangan serta praktek dinasti (kekeluargaan) dalam proses politik dan pencalonan kepala daerah.

Mereka hanya berpikir bagaimana caranya untuk membayar biaya selama proses pemilu. Kenyataan ini bukanlah sebuah demokrasi melainkan pluktorasi; istilah dari Aristoteles yang mengacu pada dominasi orang-orang kaya di dalam mengendalikan pemerintahan. Pengaruh lain dari rent seeking adalah oligarki. Indonesia setelah rezim otoriter, menunjukkan bahwa sebagian besar elit politik dan para pemimpin hanya fokus pada perang argumen satu sama lain dan bagaimana cara memperoleh kekuasaan daripada memikirkan bagaimana cara untuk membangun perekonomian Indonesia.

Dalam jangka panjang negara dengan tingkat korupsi yang tinggi kesulitan untuk membiayai belanja negara karena defisit amggaran yang tinggi, rendahnya pertumbuhan ekonomi, investasi publik yang lebih tinggi, pendapatan dari sektor pajak pemerintah yang lebih rendah, pengeluaran hanya fokus pada belanja rutinitas serta realisasi belanja modal lebih rendah pada operasi bisnis yang diikuti rendahnya kualitas infrastruktur, Tanzi dan Davoodi (1997).

\section{Kajian Pustaka dan Pengembangan Hipotesis Apa itu korupsi ?}

Korupsi berasal dari bahasa latin, CorruptioCorrumpere yang artinya busuk, rusak, menggoyahkan, memutarbalik atau menyogok. Korupsi menurut Huntington (1968) adalah perilaku pejabat publik yang menyimpang dari norma norma yang diterima oleh masyarakat, dan perilaku menyimpang ini ditujukan dalam rangka memenuhi kepentingan pribadi atau kelompoknya/keluarganya. Korupsi cenderung meningkat dalam satu periode pertumbuhan sarta modernitas yang cepat, karena perubahan nilai-nilai, sumber baru kekayaan dan kekuasaan serta perluasan pemerintahan.

Dalam Kamus Bahasa Indonesia, kata "Korupsi" berasal dari kata korup yang berarti buruk, rusak, busuk, memakai barang/uang yang dipercayakan, dapat disogok. Mengkorup adalah merusak, menyelewengkan atau menggelapkan barang atau uang milik perusahaan (negara) tempat bekerja. Korupsi adalah penyelewengan atau penyalahgunaan uang negara (perusahaan dsb) untuk keuntungan pribadi atau orang lain.

Menurut Undang-Undang No.31 Tahun 1999 tentang Pemberantasan Tindak Pidana Korupsi, yang termasuk dalam tindak pidana korupsi adalah Setiap orang yang dikategorikan melawan hukum, melakukan perbuatan memperkaya diri sendiri, menguntungkan diri sendiri atau orang lain atau suatu korporasi, menyalahgunakan kewenangan maupun kesempatan atau sarana yang ada padanya karena jabatan atau kedudukan yang dapat merugikan keuangan negara atau perekonomian negara.

\section{Mengapa korupsi terjadi}

Beberapa tahun terakhir korupsi telah berubah dari sebuah isu nasional atau regional menjadi masalah global. Beberapa kepala pemerintahan telah jatuh dan digiring ke pengadilan seperti Tunisia, Mesir, India, dll. Hampir tidak ada wilayah yang bebas dari wabah 
korupsi. Skandal korupsi dan runtuhnya kerajaan Blatter di Badan Sepak Bola Dunia (FIFA) serta berlanjutnya krisis keuangan Yunani menjadi topik hangat hampir diseluruh dunia. Blatter dan Yunani menggulang sejaran-sejarah kerajaan bisnis dan pemerintahan sebelumnya yang hancur karena korupsi. Menurut E.Y. Sarna (2010) keserakan atau ketamakan awal dari terjadinya malapetaka dan kehancuran yang disebabkan oleh korupsi.

Alesina dan Drazen (1991); Tavares (2004) dan Mierau et al. (2007) berpendapat bahwa jumlah partai politik dapat mengurangi tingkat korupsi dan apabila akses ekonomi lebih berat dibanding akses ekonomi, orang akan memasuki arena politik untuk mendapatkan uang dan ini dapat menjurus kepada semakin luasnya korupsi politik dan korupsi ekonomi. Semakin partai politik itu kurang berkembang, tingkat korupsi akan semakin meluas karena lemahnya pengawasan. (Shleifer dan Vishny, 1993; Sandholtz dan Koetzle, 2000; Treisman, 2000; Agatiello, 2010; Graycar dan Sidebottom, 2012; Jetter, et. al, 2015).

Faktor sosial dan budaya memainkan peran khusus dalam mengidentifikasi tingkat korupsi suatu negara, menurut La Porta (1999), Treisman (2000) dan Alesina (2003). Agama dan sistem sosial memiliki pengaruh dalam menekan korupsi. Faktor ekonomi, seperti keterbukaan ekonomi (Dreher, 2006; Treisman, 2000), sektor publik dalam perekonomian (Tanzi, 1998; Treisman, 2000), tingkat remunerasi di sektor publik (Rijckeghem dan Weder, 1997), memiliki dampak langsung pada tingkat korupsi di sebuah negara.

\section{Tipe-tipe korupsi}

Aguilera dan Vadera (2008) membedakan tipologi korupsi berdasarkan kompleksitas dan praktek korupsi di seluruh dunia yang dilakukan oleh sebuah organisasi/perusahaan dengan menggunakan otoritas dalam organisasi untuk keuntungan pribadi/organisasi". Selanjutnya Aguilera dan Vadera (2008) membedakan tiga jenis korupsi yang dilakukan sebuah organisasi/perusahaan yakni korupsi prosedural ketika seseorang tidak mengikuti (etika) prosedur perilaku bisnis, korupsi skema jika organisasi memerlukan suap, membayar politisi dan birokrat untuk melakukan bisnis, korupsi akan menjadi bagian dari operandi, korupsi kategori ketika perusahaan diharapan melakukan tindakan tidak etis atau korupsi untuk bertahan hidup.
Zekos (2004) membahas banyak aspek korupsi dalam konteks globalisasi dan membedakan komponen-komponen korupsi berupa korupsi prinsip yakni harmonisasi prinsip etika dalam bisnis dapat berkontribusi menghentikan korupsi. Dengan kata lain, korupsi hanya bisa dihentikan dengan pelaksanaan prinsip-prinsip etika secara universal, korupsi perilaku/moral. dimana dilema etika dalam perusahaan bisnis berhubungan dengan pemimpin bisnis serta karyawan yang memilih hal-hal yang paling menguntungkan meskipun perilaku tersebut tidak etis bagi organisasi.

Hal ini didorong agar perusahaan dapat bersaing karena ketatnya persaingan di pasar global, korupsi orang/individual dimana menurut Zekos korupsi skala kecil sangat sulit untuk dihentikan, korupsi organisasi yang disebabkan dalam bisnis kadang mengandung banyak ketidakpastian keuntungan, sehingga para pemimpin bisnis cenderung melakukan "pendekatan menghindari kerugian" serta korupsi negara/pemerintah pemerintah yang korup hanya fokus pada pertumbuhan ekonomi, kompetensi tidak lagi dikembangkan sebagaimana mestinya. Dia mengatakan bahwa korupsi seperti membuat ekonomi nasional kurang efisien. Masyarakat tidak lagi mempercayai para pemimpin politik dan pegawai negeri.

\section{Korupsi dalam Tinjauan Islam}

Korupsi merupakan satu bentuk kejahatan modern. Sebagai kejahatan modern, dampak negatif yang ditimbulkannya tidak hanya mengancam keseimbangan negara, namun juga menodai prinsip keadilan, kesejahteraan rakyat, penegakan hukum, bahkan misi agama. Ketika agama datang mendeklarasikan prinsip keadilan, kejujuran dan penggunaan kewenangan sesuai fungsinya, tindakan korupsi justru melawan semua itu. Ketika Allah mengangkat manusia sebagai khalifah di muka bumi (Al-Baqarah [2]: 30), sikap amanah adalah sebuah keniscayaan yang tak bisa ditawar.

Korupsi terjadi karena pelakunya mengalami sesat pikir atas prinsip kejujuran dan amanah. Dengan demikian, bukan saja melawan moralitas secara umum, korupsi juga merupakan perlawanan atas agama, yakni perlawanan non-konfrontatif. Di dalam Islam, prinsip moderasi (wasathiyah) adalah wajah lain sebuah keadilan. Dalam salah satu varian maknanya, adil adalah menempatkan sesuatu sesuai tempatnya. 
Melakukan sesuatu secara kurang (taqshir/tafrith) tidak dapat disebut sebagai keadilan, begitu pula melakukan sesuatu secara berlebihan (ifrath). Moderasi bergerak di antara dua kutub tersebut. (Bagir, 2015)

\section{Korupsi dan Tiga Pilar Sosiologis}

Perhatian berbagai kalangan masyarakat bahkan masyarakat awam tentang korupsi memperlihatkan bahwa sebenarnya setiap pribadi di dalam masyarakat secara individu memiliki kemauan untuk menjadi lebih baik dengan memberikan sumbangsihnya bagi persoalan ini. Selain itu, keprihatinan dari berbagai kalangan masyarakat juga memperlihatkan bahwa sebenarnya persoalan korupsi memberi dampak sosial yang destruktif. Dengan kata lain, persoalan korupsi adalah persoalan sosial karena menyangkut kehidupan orang banyak (baca: masyarakat sosial) di Indonesia. (Tamawiwy-Karundeng, 2015)

Berbicara tentang aspek sosial, Perlas (2001) mengingatkan bahwa kehidupan sosial selalu terdiri atas tiga subsistem penting (three realms/three subsytems) yaitu: politik (politic), ekonomi (economy) dan budaya (culture). Ketiga subsistem ini disebut juga sebagai 'tiga pilar sosiologis'. Interaksi ketiga pilar inilah yang menentukan kehidupan sosial macam apa yang kita hidupi di Indonesia. Menurut Perlas, kita akan hidup dalam kondisi sosial yang sehat jika ketiga pilar ini saling menopang satu sama lain dan mengembangkan kemampuan mereka masing-masing untuk menyadari bahwa setiap pilar dapat memiliki pengaruh yang kuat terhadap dua lainnya.

Dengan kata lain Perlas juga mengatakan bahwa dominasi salah satu atau lebih pilar sehingga mengesampingkan bahkan menaklukkan salah satu atau dua lainnya dalam kehidupan sosial ini melahirkan kehidupan sosial yang tidak sehat. Konsepsi formasi sosial seperti ini menjadi sebuah upaya bagi pembagian kekuasaan yang menghargai budaya sebagai juga pondasi yang berdiri sejajar dengan politik dan ekonomi. Menurut Perlas, ketiga pilar ini biasanya diwakili oleh tiga institusi kunci yang berpengaruh dalam kehidupan sosial.

Perlas menunjukkan beberapa perbedaan fungsi ketiga pilar, salah satunya adalah mengenai 'dasar hubungan' (relationship bases). Dasar hubungan pemerintahan adalah peraturan/hukum (rules). Dasar hubungan bisnis adalah transaksi-transaksi (transactions). Sedangkan dasar hubungan organisasi masyarakat sipil adalah nilai-nilai (values). Dalam kaitannya dengan korupsi, jika kita melihat pendekatanpendekatan yang ditawarkan untuk penyelesaian persoalan korupsi di Indonesia, maka kita dapat mengatakan bahwa kehidupan sosial di Indonesia belum sepenuhnya sehat. Pendekatanpendekatan yang ditawarkan hingga saat ini masih berat sebelah karena tidak jarang mengesampingkan pilar ketiga yaitu budaya yang banyak juga berbicara tentang nilai-nilai manusia bahkan spiritualitas.

\section{Penelitian terdahulu}

\section{Akibat Korupsi}

Tanzi dan Davoodi (1997) mengidentifikasi 4 (empat) dampak buruk korupsi yakni rendahnya pertumbuhan ekonomi, investasi publik yang lebih tinggi, pendapatan pemerintah yang lebih rendah, pengeluaran lebih rendah pada operasi bisnis dan rendahnya kulitas infrastruktur. Hasil kajian NGO global anti korupsi itu menunjukkan, semakin parah tingkat korupsi di suatu negara, semakin tinggi ketimpangan pendapatan yang terjadi di negara tersebut. Artinya, korupsi membuat si kaya semakin kaya dan si miskin tambah miskin.

Selanjutnya Tanzi menyatakan korupsi menurunkan kemampuan pemerintah mencegah kegagalan pasar. Hasil analisis TI juga menunjukkan, semakin tinggi korupsi di suatu negara, semakin tinggi pula tingkat pengangguran di negara bersangkutan. Selanjutnya, hasil penelitian Treisman (2000) bertajuk "The Causes of Corruption: A Cross-National Study" menemukan bukti ada hubungan terbalik antara korupsi dan pertumbuhan ekonomi. Artinya, semakin tinggi korupsi di suatu negara, semakin rendah kinerja ekonomi negara tersebut.

Mauro (1995,1998) mengemukakan korupsi sangat mempengaruhi tingkat pertumbuhan ekonomi dan tingkat realisasi pengeluaran pemerintah. Pemerintah yang korup selalu menghadapi tingkat pertumbuhan ekonomi yang rendah serta mengurangi belanja di sektor pendidikan. Disisi lain anggaran dan belanja di bidang militer cenderung terus meningkat (Gupta et al., 2001). Disisi lain korupsi sangat mempengaruhi tingkat konsolidasi anggaran Arin., et.al (2011).

Alesina dan Drazen (1991); Tavares (2004) dan Mierau et al. (2007) berpendapat bahwa jumlah partai politik dapat mengurangi tingkat korupsi dan apabila 
akses ekonomi lebih berat dibanding akses ekonomi, orang akan memasuki arena politik untuk mendapatkan uang dan ini dapat menjurus kepada semakin luasnya korupsi politik dan korupsi ekonomi. Semakin partai politik itu kurang berkembang, tingkat korupsi akan semakin meluas karena lemahnya pengawasan. (Shleifer dan Vishny, 1993; Sandholtz dan Koetzle, 2000; Treisman, 2000; Agatiello, 2010; Graycar dan Sidebottom, 2012; Jetter, et. al, 2015).

Dreher, Kostogiannis dan McCorriston (2004) mengidentifikasi ada empat faktor yang menjadi penyebab munculnya korupsi, yaitu faktor politis dan judisial, faktor historis, faktor sosial dan budaya, dan faktor ekonomik. Faktor sosial dan budaya pada hakekatnya terkait dengan sikap moral. Orang yang memiliki kualitas moral yang terpuji cenderung menjauhkan diri dari perbuatan-perbuatan korupsi. Mereka cederung dalam membuat keputusan dan mengimplementasikan program dalam berbagai kegiatannya cenderung menghindarkan diri dari perbuatan-perbuatan yang merugikan orang lain atau pihak lain begitu juga sebaliknya.

Faktor sosial dan budaya memainkan peran khusus dalam mengidentifikasi tingkat korupsi suatu negara, menurut La Porta (1999), Treisman (2000) dan Alesina (2003). Agama dan sistem sosial memiliki pengaruh dalam menekan korupsi. Faktor ekonomi, seperti keterbukaan ekonomi (Dreher, 2006; Treisman, 2000), sektor publik dalam perekonomian (Tanzi, 1998; Treisman, 2000), tingkat remunerasi di sektor publik (Rijckeghem dan Weder, 1997), memiliki dampak langsung pada tingkat korupsi di sebuah negara. Selanjutnya Aguilera dan Vadera (2008) membedakan tipologi korupsi berdasarkan kompleksitas dan praktek korupsi diseluruh dunia.

Henderson dan Kuncoro (2012) meneliti aliran partai politik yang ada di Indonesia, mengemukakan faktor partai politik cukup dominan yang mempengaruhi tingkat korupsi pada suatu periode dan daerah di Indonesia yaitu partai yang berbasis agama dalam hal ini agama Islam lebih sedikit melakukan tindakan korupsi jika dibandingkan partai yang berbasis non agama. Modus kecurangan dan korupsi dilakukan dengan cara menyuap pihak politikus dan penegak hukum serta aparat birokrasi dalam mendapatkan pelayanan.

\section{Metode Penelitian}

\section{Hasil dan Pembahasan}

Berdasarkan data komisi pemberantasan korupsi (KPK) sampai tahun 2015 sebagian besar tindakan korupsi di Indonesia dilakukan dengan penyuapan, pengadaan barang dan jasa, penyalahgunaan anggaran, pungutan, perijinan dan TPPU. Semua unsur dari pemerintah baik eksekutif, legislatif maupun yudikatif menjadi pesakitan di KPK, namun sebagian besar pelaku tindakan korupsi berhubungan dengan partai politik (DPR/DPRD dan Kepala Daerah).

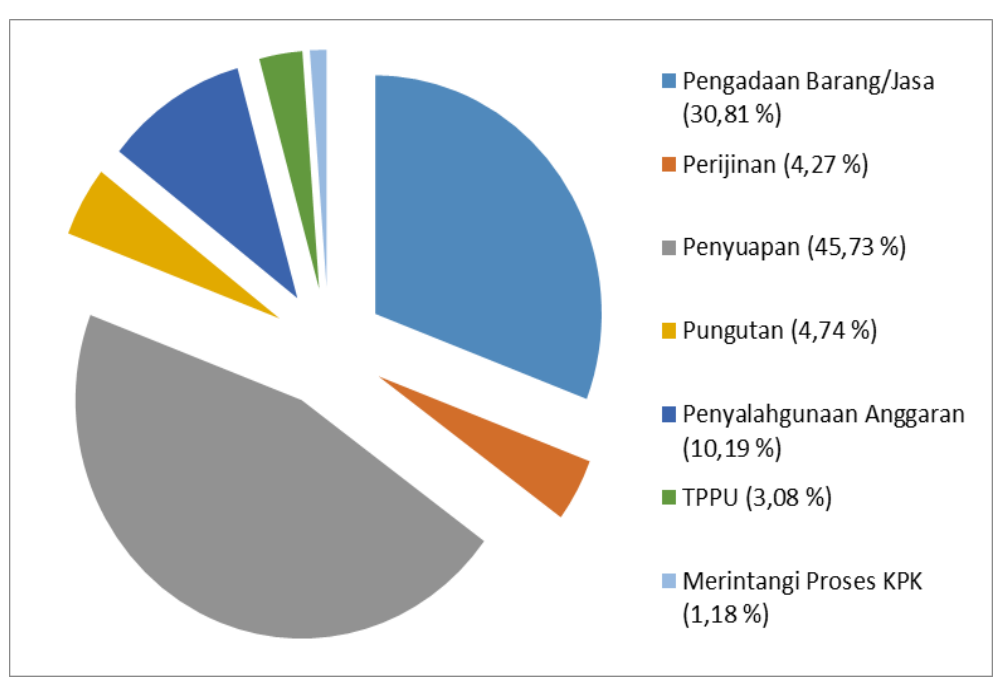

Grafik 1 : Modus tindakan korupsi (Sumber : KPK 2015)

Sebagian besar tindakan korupsi melibatkan anggota DPR/DPRD yang mempunyai wewenang penganggaran dan pihak eksekutif (menteri/kepala daerah) sebagai pihak pengguna anggaran. Direktur Jenderal Otonomi Daerah (Dirjen Otda) Kemendagri Djohermansyah Djohan mengungkapkan hingga Januari 2014 sebanyak 318 orang dari total 524 orang kepala daerah dan wakil kepala daerah tersangkut dengan kasus korupsi sejak diterapkan pilkada langsung digelar. Berdasarkan data dari ICW tahun 2014 kurang lebih 43 kepala daerah jadi tersangka, tentunya angka ini terus bertambah di tahun 2015.

Indonesia Corruption Watch (ICW) mengungkap tren korupsi di tanar air sepanjang tahun 2014, mengalami grafik peningkatan yang luar biasa. 
Semester pertama 2014, terdapat 308 kasus korupsi dengan jumlah tersangka 659 orang dan kerugian negara Rp3,7 triliun. Semester kedua, ada 321 kasus korupsi dengan 669 orang tersangka, serta kerugian negara sebesar Rp1,59 triliun. Total tahun 2014, jumlah kasus 629 kasus, jumlah tersangka 1.328 orang dan kerugian negara sebesar Rp5,29 triliun. Selama tahun 2013 ada 560 kasus, dengan tersangka korupsi sebanyak 1.271 tersangka. Tahun 2010448 kasus, ada 1.157 tersangka, tahun 2011436 kasus dengan tersangka sebanyak 1.053 tersangka dan tahun 2012 sebanyak 401 kasus dengan jumlah tersangka sebanyak 877 tersangka.

Korupsi menimbulkan distorsi (kekacauan) di dalam sektor publik dengan mengalihkan investasi publik ke proyek-proyek dimana sogokan tersedia lebih banyak. Pejabat menambah kompleksitas proyek masyarakat untuk menyembunyikan praktek korupsi, yang akhirnya menghasilkan lebih banyak kekacauan. Korupsi juga mengurangi kualitas pelayanan pemerintahan, infrastruktur serta menambahkan tekanan terhadap anggaran pemerintah, biaya barang dan jasa, yang kemudian realisasi dan kualitas anggaran yang kurang bermanfaat terhadap kesejahteraan masyarakat.

\section{Korupsi di Indonesia}

Arifianto (2004) menegaskan ada tiga teori yang dapat menjelaskan terjadinya korupsi di Indonesia, yaitu mainstream economic theory, patrimonialism theory, and kleptocratic state theory. Pertama, teori ini menjelaskan bahwa negara sering bertindak monopoli terhadap aktivitas ekonomi negara. Kedua, teori ini berpendapat bahwa korupsi dapat berperan sebagai cara untuk meningkatkan integrasi politis di antara suku bangsa, partai dan fraksi dalam pemerintahan. Ketiga, teori ini menyatakan bahwa korupsi endemik berada dalam rezim yang dikendalikan oleh pimpinan negara yang memiliki tujuan melalui posisinya hanya untuk memperkaya diri.

Harold D. Laswell dalam buku Who Gets What, When, How mengatakan: "Politik adalah masalah siapa mendapat apa, kapan, dan bagaimana. Berdasarkan pendapat inilah, cara seseorang mendapatkan kekuasaan publik dengan cara-cara tertentu, misalnya ketika seseorang memperoleh sebuah jabatan publik menggunakan cara money politics, maka ketika ia sudah menjalankan kekuasaannya, ia berpotensi melakukan tindakan-tindakan melanggar hukum dengan melakukan korupsi. Padahal korupsi merupakan tindakan melanggar hukum karena menyelewengkan kekuasaan publik untuk kepentingan tertentu.

\section{Transformasi Budaya Nusantara Dalam Pemberantasan Korupsi}

Dalam tatanan sosial dan hidup bernegara, Indonesia tidak bisa dilepaskan dari Muhammadiyah dan Nadlatul Ulama begitu juga sebaliknya. Dalam perspektif hukum pemberantasan maupun pencegahan korupsi digawangi KPK (Komisi Pemberantasan Korupsi). Bahkan gerakan moral pemberantasan korupsi juga telah di mulai pada tahun 2003 yang digawangi NU dan Muhammadiyah dalam Moment of Understanding $(\mathrm{MoU})$ tentang gerakan moral Nasional pemberantasan Korupsi. (Nasution, 1999).

Selama ini terdapat anggapan bahwa sulitnya pemberantasan korupsi di Indonesia adalah akibat pemahaman bahwa korupsi adalah budaya bangsa. Pemahaman ini perlu diluruskan dengan menunjukkan bahwa budaya bangsa Indonesia adalah anti terhadap korupsi. Indonesia adalah Negara yang bersifat pluralistik baik suku, budaya, bahasa, kepercayaan maupun agama. Keberagaman tersebut mengakibatkan keberagaman (pluralisme) hukum sebagai fakta yang tidak dapat dihindari.

Transformasi budaya nusantara ke dalam format pembangunan hukum, khususnya pemberantasan korupsi, bersumber dari 2 (dua) elemen penting : pertama, yang dihasilkan dari nilai-nilai agama; dan kedua, yang dihasilkan dari nilai-nilai adat. Budaya nusantara yang bersumber dari nilai agama antara lain dapatdilihat dari pandangan Islam yang menyatakan bahwa: "Tindak Pidana Korupsi untuk memperkaya diri dari harta negara adalah perbuatan zhalim (aniaya), karena kekayaan negara adalah harta yang dipungut dari masyarakat termasuk masyarakat miskin yang mereka peroleh dengan susah payah. Bahkan perbuatan tersebut berdampak sangat luas serta berdampak menambah kuantitas masyarakat miskin baru". (Muhlizi, 2014).

Korupsi adalah perbuatan yang dikategorikan membuat kerusakan di bumi. Lebih jauh hal ini dijelaskan dalam Fatwa Ulama Nahdlatul Ulama (NU) pada Munas Alim Ulama dari kalangan NU di Asrama Haji Pondok Gede, Agustus 2002 yang mengemukakan halhal sebagai berikut : 
(1) Dalam pandangan syariat, korupsi merupakan penghianatan berat (ghulul) terhadap amanat rakyat. Dilihat dari cara kerja dan dampaknya, korupsi dapat dikategorikan sebagai pencurian (sariqah), perampokan (nahb);

(2) Pengembalian uang korupsi tidak menggugurkan hukuman. Karena tuntutan hukuman merupakan hak Allah, sementara pengembalian uang korupsi ke Negara merupakan hak masyarakat (hak adamiy). Hukuman yang layak untuk koruptor adalah potong tangan sampai dengan hukuman mati;

(3) Money politics sebagai pemberian (berupa uang atau benda lain) untuk mempengaruhi dan atau menyelewengkan keputusan yang adil dan obyektif dalam pandangan syariat merupakan suap (risywah) yang dilaknat Allah, baik yang memberi (rasyi), yang menerima (murtasyi), maupun yang menjadi perantara (raaisyi).

Dalam agama Kristen, korupsi juga sangat dilarang, karena : pertama, korupsi identik dengan mencuri. Dalam 10 Perintah Tuhan, larangan kedelapan adalah larangan untuk mencuri. 10 Perintah Tuhan adalah salah satu norma yang dituangkan di Alkitab Perjanjian Lama dan merupakan inti dari etika Alkitab Perjanjian Lama. Dalam Keluaran 20:15, Allah berfirman: Jangan mencuri. Sementara itu korupsi adalah mencuri dengan cara diam-diam, dengan cara halus mengurangi hak negara atau orang lain demi kepentingan pribadi. Larangan mencuri juga dikemukakan Yesus dalam bentuk yang berbeda, yaitu hukum mengasihi sesama manusia seperti diri sendiri (Matius 22: 39; Mark 12: 31; Lukas 10: 27).

Larangan korupsi juga ditemukan dalam agama Buddha yang mengatakan: "tujuan hidup yaitu nirwana (puncak), manusia korup akan tak bahagia”, kemudian agama Hindu yang menyebutkan: "pemimpin korup tak akan hidup kembali, suap sebagai pintu masuk dosa, pendosa tak diakui oleh Tuhan dan kena karma", serta Konfusianis yang menyatakan : "pendidikan beretika, pengendalian diri, pemerintahan akan hancur bila rakyat sudah tak menaruh kepercayaan terhadapnya."

Luca pacioli yang dikenal sebagai bapak akuntansi modern pada awal memperkenalkan metode pencatatan sangat memahami fenomena ini. Oleh karena itu disetiap pembuatan laporan keuangan selalu diawali dengan kata "tepujilah tuhan". Hal ini berdasakan apa yang dilihatnya dari para pedagang arab selalu mengawali setiap kegiatannya dengan kata "Bismillahi rahmanni rahim", semua aktivitas wajib memohon ridho dari Allah SWT karena tidak ada kejadian tanpa ijin Allah SWT.

Di era modern segalanya telah berubah kata yang sangat mulia diganti dengan sesuatu yang berbau materi yakni laporan posisi keuangan, laporan laba rugi, laporan perubahan modal dan laporan arus kas. Disinilah awal masalahnya, berapa banyak kecurangan akuntansi di dunia seperti Enron, Xerox, Kanebo, dan lain-lain. Terbaru di Indonesia bagaimana seorang auditor senior BPK ditangkap KPK karena melakukan praktek fraud.

Banyak pihak berpendapat salah satu solusinya kembali ke sistem syariah sebagaimana yang dipraktekkan perbankan syariah. Dibandingkan dengan laporan keuangan perbankan syariah di Timur Tengah, disetiap laporannya diawali dengan kata "Bismillahi Rahmani Rahim". Hal tersebut tidak ditemukan di laporan keuangan perbankan syariah di Indonesia.

\section{Simpulan}

Di Indonesia korupsi secara langsung mempengaruhi dan memiliki korelasi negatif dengan tingkat investasi, pertumbuhan ekonomi, dan pengeluaran pemerintah untuk program sosial dan kesejahteraan. Hal-hal ini merupakan bagian dari inti ekonomi makro. Hal ini sama dengan kesimpulan Mauro (1995); Olson (1993, 2000); Henderson dan Kuncoro (2011) yang menyatakan demokrasi tidak berkorelasi positif dengan pertumbuhan ekonomi dan mengurangi tingkat korupsi.

Proses demokrasi di Indonesia berkorelasi dengan korupsi. perubahan politik hanya merubah tipe korupsinya. Demokrasi menciptakan korupsi baru dan mengarah kepada kerusuhan suku, agama dan ras. Kesimpulan ini sesuai dengan Agatiello (2010); Jetter, Agudelo dan Hasan (2015) yakni sistem demokrasi efektif mengurangi tindakan korupsi hanya terjadi pada negara yang tergolong maju dan makmur. Salah satu hal yang menjadi penyebab suburnya korupsi selama ini adalah pendekatan yang digunakan dalam pencegahan korupsi sedikit melupakan faktorfaktor budaya dan agama mengingat bagsa Indonesia terdiri dari berbagai macam budaya dan agama. 
Karena, seperti tampak jelas dalam berbagai tradisi tekstual Islam, adalah amal-amal buruk yang akan menyebabkan kotornya "hati" ini. Nah, untuk bisa membuat pengetahuan dan sikap hati itu benarbenar menjadisecond nature diperlukan latihanlatihan (exercises) -

yang dalam pendidikan keagamaan (tarbiyah atau, tepatnya, ta'dib) - disebut sebagai riyadhah (maknaaslinya memang adalah 'latihanlatihan').

Menurut Al-Farabi, tak mungkin seseorang sejak lahir dianugerahi sifat-sifat baik atau buruk. Meskipun demikian, ia boleh jadi dianugerahi kesiapan-kesiapan alami (disposisi atau isti'dad) bagi perilaku-perilaku baik dan buruk tersebut. Kesiapan ini, melalui praktik, dapat berkembang menjadi suatu kebiasaan (hay'ah atau habitus) yang, sekali tertanam dalam jiwa, disebut kebaikan atau keburukan. 14 Maka,berbeda dengan pengetahuan mengenai moralitas (baik-buruk) yang bertempat dan beroperasi dalam akal teoretis sebagaimana di atas, dorongan untuk melakukan tindakan moral sesungguhnya terdapat di akal praktis. Akal praktis ini berurusan dengan nafsu, emosi, serta estimasi dan imajinasi. Ia berperan dalam memprakarsai dan menggesa, serta mengarahkan dan mengoordinasikan sebuah tindakan. Bersama dengan akal teoretis, akal praktis melahirkan kaidah-kaidah umum moralitas, dan memberikan pengaruh penyeimbang terhadap fungsi-fungsi jasmani dan, dengan demikian, memastikan keselarasannya dengan norma-norma kebajikan.

Perlunya menumbuhkan kesadaran kepada pihak-pihak pengambil keputusan di perbankan syariah seperti DPS, SSB dan IAI kompartemen akuntansi syariah untuk memuat kata yang begitu akrab dan pendek namun memberikan dampak yang besar dalam mencegah korupsi dan kecurangan laporan keuangan. Hal ini menyangkut tanggung jawab bukan hanya kepada stakeholders melainkan kepada Allah SWT.

\section{Referensi}

[1] Agatiello, O,R; (2010); Corruption not an end Geneva School of Diplomacy and International Relations, Geneva, Switzerland, Management Decision Vol. 48 No. 10; pp. 1456-1468

[2] Alesina, A., Drazen, A., (1991), Why are stabilisations delayed? The American Economic Review 81 (5), 1170-1188.
[3] Bagir, Haidir, (2015), Korupsi dari perspektif filsafat dan etika Islam, Etika dan Religiusitas Anti-Korupsi (dari konsep ke praktek di Indonesia), Geneva: Globethics.net

[4] Dreher, A, (2006), Does globalization affect growth? Evidence from a new index of globalization, Applied Economics, 38, 10911110 .

[5] Graycar, A dan Sidebottom, A; (2012),"Corruption and control: a corruption reduction approach", Journal of Financial Crime, Vol. 19 Iss 4 pp. 384-399

[6] http://www.hukumonline.com/berita/baca/lt54afe bb14ae5a/ini-10-kepala-daerah-yang-tersandungkorupsi-di-2014; diakses pada 21 Juli 2015

[7] Hadiz, V.R dan Robinson, R; (2004); Reorganising power in Indonesia : the politics of oligarchy in an age of Markets; New York : RoutledgeCurzon, pp. 136-167

[8] Henderson, J.V dan Kuncoro, A, (2011), Corruption and local democratization in Indonesia: The role of Islamic parties, Journal of Development Economics 94 , p. 164-180

[9] Iqbal, Z. dan Lewis, M.K. (2002), "Governance and corruption: can Islamic societies and the westclearn from each other?", American Journal of Islamic Social Sciences, Vol. 19, pp. 1-33, Part 2.

[10] Jetter, M, Agudelo A.M, dan Hasan, A.R; (2015), The Effect of Democracy on Corruption: Income is Key; World Development Vol. 74, pp. 286304

[11]Komisi pemberantasan korupsi (2015), "http://acch.kpk.go.id/en/statistikpenanganantindak-pidana-korupsi-berdasarkan-jenis-perkara (accessed 19 juli 2015).

[12] Mauro, P., (1995), Corruption and growth. Quarterly Journal of Economics 110, 681-712.

[13] Mauro, P., (1998), Corruption and the composition of government expenditure. Journal of Public Economics 69, 263-279.

[14] Mierau, J., Jong-A-Pin, R., de Haan, J., 2007. Do political variables affect fiscal policy adjustment decisions? New empirical evidence. Public Choice 133 (3), 297-319.

[15] Muhlizi, A.F, 2014, revolusi mental untuk membentuk budaya hukum anti korupsi, Jurnal Rechtsvinding, Vol 3 No 3 
[16] Olson, M., (1993), Dictatorship, democracy, and development. American Political Science Review 87, 567- 576.

[17] Olson, M., (2000), Power and Prosperity: Outgrowing Communist and Capitalist Dictatorships. Basic Book, New York.

[18] Perlas, Nicanor, 2001, "Social Threefolding", dalam Nicanor Perlas, Shaping Globalization: Civil Society, Cultural Power and Threefolding, dalam http://www.globenet3.org/threefold.shtml, diakses tanggal 20 Desember 2015

[19] Rijckeghem, R.V dan Weder, B, (1997), 'Corruption and the Rate of Temptation: Do Low Wages in the Civil Service Cause Corruption?' (Washington, D.C.: IMF Working Paper No. 97/93

[20] Rose-Ackerman, S. (1978), Corruption: A Study in Political Economy, Academic Press, New York, NY.

[21]Rose-Ackerman, S. (2000), "Corruption and government: causes, consequences, and reform", Public Choice, Vol. 104, pp. 1-2.

[22] Sandholtz, W dan Koetzle. W, (2000) 'Accounting for Corruption: Economic Structure, Democracy, and Trade', International Studies Quarterly, 31-50

[23] Shleifer, A dan Vishny, R.W, (1993), 'Corruption', Quarterly Journal of Economics, 108, 599-617.

[24] Tamawiwy-Karundeng, A.C, , (2015), Korupsi dari perspektif filsafat dan etika Islam, Etika dan Religiusitas Anti-Korupsi (dari konsep ke praktek di Indonesia), Geneva: Globethics.net

[25] Tanzi, V., Davoodi, H., (1997), Corruption, public investment, and growth. IMF Working Paper WP/97/139.

[26] Tanzi, V., (1998), Corruption around the world: causes, scope and cures. IMF Staff Papers 45, 559-594.

[27] Tavares, J., (2004), Does right or left matter? Cabinets, credibility and fiscal adjustments, Journal of Public Economics 88 (12), 2447-2468.

[28] Transparency International (2014), Transparency International 2014 Annual Report.

[29] Treisman, D., (2000), The causes of corruption: a cross-national study. Journal of Public Economics 76 (3), 399-457.
[30] www.kompas.com, 04 Juni 2015, diakses 1 Juli 2015

[31] www.Liputan6.com, diakses pada 24 Maret 2015

[32] www.beritasatu.com/hukum/249903-icw-43kepala-daerah-tersangka korupsi-dominanberafiliasi-ke-partai-tertentu.html; diakses pada 21 Juli 2015

[33]Zekos, G.I. (2004), "Ethics versus corruption in globalization", Journal of Management Development, Vol. 23 No. 7, pp. 631-647. 